OPEN ACCESS

Edited by:

Honoo Satake,

Suntory Foundation for Life Sciences,

Japan

Reviewed by:

Valerie Simonneaux,

Centre National de la Recherche

Scientifique (CNRS), France

Kataaki Okubo,

The University of Tokyo, Japan

*Correspondence:

You Lee Son

youleeson@keio.jp

Specialty section:

This article was submitted to Experimental Endocrinology,

a section of the journal

Frontiers in Endocrinology

Received: 22 November 2018 Accepted: 06 February 2019

Published: 25 February 2019

Citation:

Son YL, Ubuka T and Tsutsui K (2019)

Molecular Mechanisms of Gonadotropin-Inhibitory Hormone (GnIH) Actions in Target Cells and

Regulation of GnIH Expression.

Front. Endocrinol. 10:110

doi: 10.3389/fendo.2019.00110

\section{Molecular Mechanisms of Gonadotropin-Inhibitory Hormone (GnlH) Actions in Target Cells and Regulation of GnIH Expression}

\author{
You Lee Son ${ }^{1,2 *}$, Takayoshi Ubuka ${ }^{2}$ and Kazuyoshi Tsutsui ${ }^{2}$ \\ ${ }^{1}$ Laboratory of Photobiology, Department of Ophthalmology, Keio University School of Medicine, Tokyo, Japan, ${ }^{2}$ Laboratory \\ of Integrative Brain Sciences, Department of Biology and Center for Medical Life Science, Waseda University, Tokyo, Japan
}

Since gonadotropin-inhibitory hormone $(\mathrm{GnlH})$ was discovered in 2000 as the first hypothalamic neuropeptide that actively inhibits gonadotropin release, researches conducted for the last 18 years have demonstrated that $\mathrm{GnlH}$ acts as a pronounced negative regulator of reproduction. Inhibitory effect of $\mathrm{GnlH}$ on reproduction is mainly accomplished at hypothalamic-pituitary levels; gonadotropin-releasing hormone $(\mathrm{GnRH})$ neurons and gonadotropes are major targets of $\mathrm{GnlH}$ action based on the morphological interaction with $\mathrm{GnlH}$ neuronal fibers and the distribution of $\mathrm{GnlH}$ receptor. Here, we review molecular studies mainly focusing on the signal transduction pathway of $\mathrm{Gn} l \mathrm{H}$ in target cells, GnRH neurons, and gonadotropes. The use of well-defined cellular model systems allows the mechanistic study of signaling pathway occurring in target cells by demonstrating the direct cause-and-effect relationship. The insights gained through studying molecular mechanism of $\mathrm{GnIH}$ action contribute to deeper understanding of the mechanism of how GnlH communicates with other neuronal signaling systems to control our reproductive function. Reproductive axis closely interacts with other endocrine systems, thus GnIH expression levels would be changed by adrenal and thyroid status. We also briefly review molecular studies investigating the regulatory mechanisms of $\mathrm{GnlH}$ expression to understand the role of $\mathrm{GnlH}$ as a mediator between adrenal, thyroid and gonadal axes.

Keywords: gonadotropin-inhibitory hormone/RFamide-related peptides (GnIH/RFRPs), GnIH receptor (GnIH-R), gonadotropin-releasing hormone (GnRH), kisspeptin, vasoactive intestinal polypeptide (VIP), gonadotropes, glucocorticoid (GC), thyroid hormone (TH)

\section{INTRODUCTION}

Gonadotropin-inhibitory hormone $(\mathrm{GnIH})$ was initially isolated from the Japanese quail hypothalamus that inhibited gonadotropin release from the cultured quail anterior pituitary; this was the first demonstration of a hypothalamic neuropeptide directly inhibiting gonadotropin release in any vertebrate (1). GnIH peptides have since been identified in all vertebrate classes, and these share an LPXRFamide ( $X=\mathrm{L}$ or Q) motif at their C-termini (24), thus also known as RFamide-related peptides (RFRPs). In mammals, GnIH precursor gene is translated and cleaved into at least two peptides, RFRP1 and 3 (2-4). Not only the presence of GnIH/RFRP peptides, but their function to inhibit gonadotropin secretion is also conserved across mammals, including mice, rat and humans (2, 3, 5-8). 
Two G protein-coupled receptors, GPR147 and GPR74 have been identified as GnIH receptors (GnIH-Rs) (9-12). Yin et al. identified that membrane fraction of COS-7 cells transfected with quail GPR147 binds specifically to GnIH (12). Ikemoto and Park cloned GnIH-Rs in the chicken; GPR147 cDNA was only expressed in the brain and pituitary, whereas GPR74 cDNA was ubiquitously expressed in various tissues (11). In mammals, Hinuma et al. identified a specific receptor for RFRP and named it OT7T022, which was identical to GPR147 (10). Bonini et al. reported two GPCRs for neuropeptide FF (NPFF), which has PQRFamide motif at its C-terminal, NPFF1 (identical to GPR147) and NPFF2 (identical to GPR74) (9). From the higher GnIH binding affinity for GPR147 than GPR74, GPR147 is thought to be the principal receptor for $\operatorname{GnIH}(9,11)$. GnIH$\mathrm{R}$ couples to $\mathrm{G} \alpha \mathrm{i}$, which inhibits the activity of adenylate cyclase (AC), thus reducing intracellular CAMP levels and protein kinase A (PKA) activity $(10,13-15)$. Cell bodies of $\mathrm{GnIH}$ neurons are located in the paraventricular nucleus (PVN) in birds (1, $16,17)$ and in the dorsomedial hypothalamic area $(\mathrm{DMH})$ in most mammals (10, 18-21). The projection of GnIH neurons to gonadotropin-releasing hormone $(\mathrm{GnRH})$ neurons is the most conserved property of $\mathrm{GnIH}$ neurons. GnIH neuronal axon terminals contact with GnRH neurons in axo-somatic as well as axo-dendritic contacts, that express GnIH-R in the preoptic area (POA) $(18,21-25)$. GnIH neuronal fibers are also observed in the median eminence to control anterior pituitary function via GnIH-R expressed in gonadotropes $(1,6,7,17,22,26,27)$.

As reviewed elsewhere $(2,3,8,15,28-31)$, much evidence now supports the notion of $\mathrm{GnIH}$ as a key neurohormone to inhibit reproduction by regulating the hypothalamic-pituitary function. Recent studies for deeper understanding of the detailed molecular mechanisms of $\mathrm{GnIH}$ action have reinforced the physiological significance of $\mathrm{GnIH}$ in reproductive regulation. Here, we address selective studies demonstrating the $\mathrm{GnIH}$ action mechanism uncovered by using cellular and molecular model systems.

\section{POTENTIAL SIGNALING PATHWAYS THAT CONVEY THE INHIBITORY ACTION OF GNIH IN GNRH NEURONS}

\section{Regulators of GnRH Neuronal Function}

$\mathrm{GnRH}$ is the final output of the brain that regulates reproduction by stimulating gonadotropin secretion, thus $\mathrm{GnRH}$ neuronal functions are finely tuned by various stimulatory and inhibitory signals. There is strong evidence supporting a direct suppressive effect of GnIH on GnRH neuronal activities. Direct application of $\mathrm{GnIH}$ to hypothalamic brain slices decreases the firing rate of a subpopulation of GnRH neurons (32) and a direct postsynaptic inhibition of $\mathrm{GnRH}$ neuronal firing may occur via GnIH-mediated hyperpolarization of $\mathrm{K}^{+}$channels in vGluT2-GnRH neurons (33). Similarly, intracerebroventricular administration of $\mathrm{GnIH}$ suppresses c-Fos immunoreactivity in GnRH neurons (34).

Following the discovery of GnIH, kisspeptin, encoded by the kiss1 gene (35), was demonstrated to play an important role in the up-regulation of the reproductive system in mammals (3638). In contrast to $\mathrm{GnIH}$ actions, kisspeptin treatment potently activates electrical firing of GnRH neurons in hypothalamic slices $(39,40)$. Kisspeptin neurons make close contact with $\mathrm{GnRH}$ neurons acting at both the cell body and the nerve terminals $(41,42)$. The majority of GnRH neurons express the receptor for kisspeptin, GPR54 (43), which couples to $\mathrm{G} \alpha_{\mathrm{q} / 11}$ to activate phospholipase $\mathrm{C}$ and $\mathrm{Ca}^{2+}$ mobilization (44). Numerous studies have shown that kisspeptin acts as a key stimulatory regulator of the GnRH system (45).

Neurons synthesizing vasoactive intestinal polypeptide (VIP) are located in the suprachiasmatic nucleus (SCN) core subregion and have monosynaptic connections with $\mathrm{GnRH}$ neurons (46, 47). GnRH neurons express the VIP/PACAP receptor subtype 2 (VPAC2) (48), which is preferentially coupled to the $\mathrm{G} \alpha_{\mathrm{s}}$ signal transduction pathway that leads to accumulation of cAMP (49). VIP-targeted GnRH neurons preferentially express c-Fos during the afternoon of the luteinizing hormone ( $\mathrm{LH}$ ) surge on the day of proestrus $(50,51)$, and blocking VIP signaling via in vivo antisense antagonism abolishes $\mathrm{GnRH} / \mathrm{c}$ Fos activation in ovariectomized, estradiol-treated female rats (52, 53). Additionally, electrical responses of $\mathrm{GnRH}$ neurons to exogenous VIP exhibited peak activity around the predicted onset of the LH surge (54). Together, these lines of evidence suggest that VIP may facilitate GnRH release that leads to the preovulatory LH surge.

\section{Possible Interaction Between GnIH and Kisspeptin Signalings}

From the opposite effects of kisspeptin and $\mathrm{GnIH}$ on the $\mathrm{GnRH}$ neuronal system, the interaction of their signal transduction pathways is expected to finetune the GnRH neuronal activity. The use of well-defined in vitro GnRH neuronal model system allows to examine their possible interaction occurring in $\mathrm{GnRH}$ neurons. GT1-7 is a clonal line of mature $\mathrm{GnRH}$ neurons of mouse hypothalamus (55). GT1-7 cells exhibit neuronal morphology with synapse formation and secrete mature $\mathrm{GnRH}$ in a pulsatile fashion, similar to $\mathrm{GnRH}$ neurons in vivo $(55,56)$. GT1-7 cells express GnIH-Rs, GPR147 and GPR74, as well as GPR54 (57-60), and the stimulatory effect of kisspeptin on GnRH system in GT1-7 cells has been demonstrated (57, 61-63). However, there was yet no evidence for direct inhibitory effect of $\mathrm{GnIH}$ on kisspeptin-induced signaling pathway in $\mathrm{GnRH}$ neurons. As the major downstream signaling events induced by kisspeptin/GPR54 in GT1-7 cells, $\mathrm{Ca}^{2+}$ mobilization-related nuclear factor of activated T-cells response element (NFAT$\mathrm{RE})$ activity and protein kinase $\mathrm{C}$ (PKC)-mediated extracellularsignal-regulated kinase (ERK)/mitogen activated protein kinase (MAPK) activity has been identified. However, it has been shown that $\mathrm{GnIH}$ has no inhibitory effect on these activities, even if GPR147 is overexpressed (60) (Figure 1). Although GnIH does not directly inhibit $\mathrm{G} \alpha_{\mathrm{q} / 11}$-mediated activities induced by kisspeptin in GT1-7 cells, there is strong evidence showing that $\mathrm{GnIH}$ may be involved in $\mathrm{Ca}^{2+}$ or PKC-related signaling pathway. Clarke et al. have found that ovine GnIH (RFRP3) potently blocks the generation of intracellular free $\mathrm{Ca}^{2+}$ in 


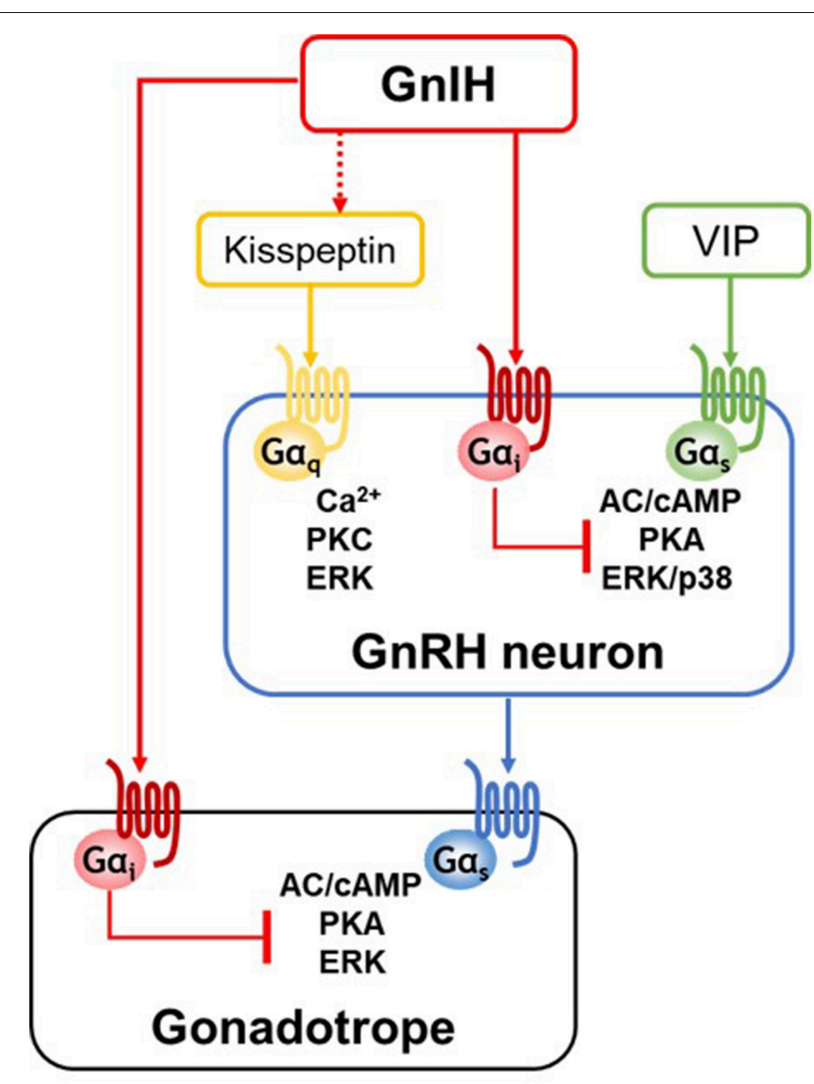

FIGURE 1 | A schematic representation of GnIH action at the hypothalamic-pituitary levels. GnlH neurons project to hypothalamic $\mathrm{GnRH}$ neurons and pituitary gonadotropes, and $\mathrm{GnlH}$ directly acts via $\mathrm{G} \alpha_{i}$-coupled GPR147 or GPR74 expressed in its target cells. GnRH neurons are activated by kisspeptin or vasoactive intestine peptide (VIP) stimulation. GnlH has no direct inhibitory effect on kisspeptin/ $\mathrm{G} \alpha_{\mathrm{q}}$-coupled GPR54-induced $\mathrm{Ca}^{2+}$ or PKC pathway. Although kisspeptin/GPR54 pathway is not the direct target of $\mathrm{GnlH}$ action, $\mathrm{GnlH}$ may regulate kisspeptin neuronal activity via direct fiber contact and $\mathrm{GnlH}$ receptor expressed in kisspeptin neurons. On the other hands, GnlH effectively inhibits VIP/G $\alpha_{S}$-coupled VPAC2-induced pathway by specifically acting on adenylate cyclase (AC)/CAMP/protein kinase A (PKA)-dependent pathway. In gonadotropes, GnlH exerts its inhibitory effect via $A C / c A M P / P K A$ pathway, thus $\mathrm{G} \alpha_{S}$-coupled $\mathrm{GnRH}$ receptor signaling is specifically inhibited by $\mathrm{GnlH}$.

the pituitary elicited by $\mathrm{GnRH}$, although they did not directly investigate the site of ovine $\mathrm{GnIH}$ action within the $\mathrm{Ca}^{2+}$ system (26). Reversely, Nichols et al. have shown that PKC inhibitor blocks human RFRP1 activity in cardiomyocytes, suggesting that RFRP1 activates PKC pathway to modulate cardiac contractile performance (64). Nevertheless, the effect of GnIH on kisspeptininduced $\mathrm{Ca}^{2+}$ or PKC pathway has not yet been verified.

A study using another GnRH neuronal cell model, mHypoAGnRH/GFP, generated from adult-derived GnRH-GFP neurons, shows the interaction of $\mathrm{GnIH}$ and kisspeptin on $\mathrm{GnRH}$ transcriptional regulation (65). In mHypoA-GnRH/GFP cells, treatment of $\mathrm{GnIH}$ attenuates basal GnRH mRNA expression, whereas kisspeptin induces $\mathrm{GnRH}$ levels. Co-treatment of $\mathrm{GnIH}$ and kisspeptin suppresses GnRH mRNA expression, suggesting the inhibitory effect of $\mathrm{GnIH}$ may override the stimulatory effect of kisspeptin on GnRH mRNA expression. By using transcriptional inhibitors (actinomycin D and DRB), Gojska et al. further show that GnIH-mediated repression is involved in new RNA synthesis rather than affecting the stability of pre-existing GnRH mRNA in mHypoA-GnRH/GFP cells (65). Although they present a novel action mechanism of $\mathrm{GnIH}$ on $\mathrm{GnRH}$ transcriptional regulation, these results do not indicate the direct inhibitory effect of $\mathrm{GnIH}$ on kisspeptin-induced signaling pathway.

Interestingly, it was shown that GnIH effectively suppresses kisspeptin-induced $\mathrm{GnRH}$ release in hypothalamic culture of adult mice (60). This phenomenon may be a result from the inhibition of $\mathrm{GnIH}$ effects on exocytosis of $\mathrm{GnRH}$, not on kisspeptin/GPR54 signaling pathway in GnRH neurons. It would be also explained by the action of $\mathrm{GnIH}$ on kisspeptin neurons. Compared with GnRH neuronal cell models, there exist several neuronal networks for the actions of $\mathrm{GnIH}$ and kisspeptin controlling GnRH release in hypothalamic culture, similar to the in vivo environment. In this respect, GnIH may not directly interfere with the stimulatory effect of kisspeptin on GnRH neurons; but rather regulate the kisspeptin neuronal activity leading to $\mathrm{GnRH}$ release. It has been shown that $\sim 25 \%$ of kisspeptin neurons in the arcuate nucleus express GPR147 or GPR74, where $\sim 35 \%$ of arcuate kisspeptin cells received $\mathrm{GnIH}$ fiber contacts (66), suggesting a regulatory role of $\mathrm{GnIH}$ mediated signaling in arcuate kisspeptin neurons.

\section{Inhibitory Action of GnIH on VIP/VPAC2 Signaling and its Physiological Significance} GT1-7 cells specifically express VPAC2 but not VPAC1 likewise GnRH neurons in situ and well respond to VIP stimulation $(60,61,67,68)$. Our recent study using GT1-7 cells clearly shows that GnIH suppresses the stimulatory effect of VIP at multiple levels, cAMP-response element (CRE) activity, ERK and p38 MAPK pathways, and c-Fos expression (60). In this study, the use of pharmacological inhibitor H89, which is specific to PKA pathway, but not the PKC inhibitor GF-109203X, results in an inhibition of VIP-induced pathways. Furthermore, it has been shown that ERK and p38 pathways activated by forskolin, which raise cAMP level, are effectively inhibited by $\mathrm{GnIH}$, but $\mathrm{GnIH}$ has no inhibitory effect on PKC activator PMA (phorbol 12myristate 13-acetate)-induced pathways (60), demonstrating the specific inhibitory action of $\mathrm{GnIH}$ on the cAMP/PKA pathway in GnRH neurons as in gonadotropes (Figure $\mathbf{1}$ and see also the section Specific inhibition of GnRH-induced signaling via cAMP pathway in gonadotropes by $\mathrm{GnIH}$ ). Supporting this specific inhibitory role of GnIH on VIP-induced pathway shown in GT17 cells, GnIH eliminates the stimulated effect of VIP on GnRH release in female mouse hypothalamic explants (60).

It is hypothesized that VIP input is required for appropriate $\mathrm{LH}$ pulse frequencies and induction of an appropriately timed LH surge $(52,69,70)$. The SCN of female rats, compared to males, have significantly greater VIP innervation of GnRH neurons (47), suggestive of a specific role for VIP in the regulation of estrous cycle. The necessity of VIP in triggering the afternoon GnRH surge has been also suggested $(51,52)$. These findings suggest 
that direct VIP projections from the SCN to GnRH system positively drive the GnRH/LH surge. Given the pronounced inhibitory actions of GnIH on VIP/VPAC2 signaling in GT17 cells and VIP-induced GnRH release (60), it seems probable that $\mathrm{GnIH}$ may regulate LH surge by suppressing VIP action on $\mathrm{GnRH}$ neurons. The inhibitory effect of GnIH on LH surge has been reported. Treatment of female rats with $\mathrm{GnIH}$ results in marked inhibition of GnRH neuronal activity at the time of $\mathrm{LH}$ surge (34) and intravenous infusion of GnIH blocks estrogeninduced LH surge in ewes (71). Henningsen et al. also showed that acute intracerebroventricular injection of $\mathrm{GnIH}$ just before the LH surge reduces the LH surge amplitude in female Syrian hamster (72). These findings have demonstrated the inhibitory role of $\mathrm{GnIH}$ on the amplitude of GnRH/LH surge, although the direct relationship between $\mathrm{GnIH}$ and VIP has not been investigated. Notably, SCN-derived VIP fibers project to GnIH neurons in female Syrian hamster, and central administration of VIP reduced c-Fos immunoreactivity in GnIH neurons in a timedependent manner (73), indicating the possible SCN regulation of GnIH activity by VIP to control the timing of LH surge. Future studies are required to fully demonstrate the physiological relevance of interaction between GnIH and VIP on the timing and amplitude of GnRH/LH surge.

\section{INHIBITORY MECHANISM OF GNIH ACTION IN GONADOTROPES \\ Regulators of Pituitary Gonadotrope Activity}

In addition to the role of $\mathrm{GnIH}$ at the hypothalamic level, GnIH neurons also project to the median eminence to control anterior pituitary function via GnIH-R expressed in gonadotropes (6, $7,26,27)$. On the other hand, there are relatively few or no GnIH fibers in some birds (74) and rodents $(18,21,75)$, and GnIH has no direct inhibitory effect on LH secretion by the pituitary gonadotropes $(34,75,76)$. Although there is some debate whether GnIH can directly act on the pituitary in some species, GnIH decreases the synthesis and/or release of pituitary gonadotropins, $\mathrm{LH}$ and follicle-stimulating hormone (FSH) in many species $(24,26,77-80)$.

$\mathrm{GnRH}$ is the major activator of gonadotropes. Upon binding to its receptor (GnRH-R) on gonadotropes, GnRH stimulates the synthesis and release of LH and FSH (81). GnRH-R is a member of GPCR family (82). Most of the biological actions of GnRH are mediated by $\mathrm{G} \alpha_{\mathrm{q} / 11}$-coupled pathway (83). However, $\mathrm{GnRH}$ signaling may not be exclusively linked to $\mathrm{G} \alpha_{\mathrm{q} / 11}$-pathway, but also involve other pathways depending on the cell context (84). In fact, GnRH-R was shown to be coupled to $G \alpha_{s}(85,86)$. In primary pituitary culture, rat pituitary-derived G-GH3 cells and mouse gonadotrope $L \beta T 2$ cells, GnRH-R couples to $\mathrm{G} \alpha_{s}$ as well as $\mathrm{G} \alpha_{\mathrm{q} / 11}$, whereas in $\alpha \mathrm{T} 3-1$ pituitary precursor cells, CHO-K1 and COS-7 cells, GnRH-R seems to couple exclusively to $\mathrm{G} \alpha_{\mathrm{q} / 11}$ (8789). Several studies have also suggested a physiological role of cAMP as a mediator of $\mathrm{GnRH}$ actions via $\mathrm{G}_{\mathrm{s}}$-coupled pathway in the pituitary gland. A cell-permeable peptide that uncouples $\mathrm{G} \alpha \alpha_{s}$ from receptors is able to inhibit ERK and c-Fos activation, and $\mathrm{LH} \beta$ expression in $\mathrm{L} \beta \mathrm{T} 2$ cells, indicating that $\mathrm{G} \alpha_{\mathrm{s}}$ is involved in GnRH-R signaling (86).

\section{Specific Inhibition of GnRH-Induced Signaling via cAMP Pathway in Gonadotropes by GnIH}

It was shown that $\mathrm{GnIH}$ inhibits gonadotropin synthesis and/or release from cultured pituitaries in birds $(1,90)$ and mammals $(79,91,92)$. Based on the characteristic of $\mathrm{G}_{\mathrm{i}}$-coupled $\mathrm{GnIH}$ Rs, it is expected that GnIH inhibits cAMP-related signaling pathways triggered by $\mathrm{GnRH}$ in gonadotropes. Using the L $\beta \mathrm{T} 2$ gonadotrope model system, the detailed mechanisms underlying the inhibitory effect of $\mathrm{GnIH}$ on gonadotropin synthesis has been investigated (93). L $\beta$ T2 cells exhibit the characteristics of fully differentiated gonadotropes, including the expression of $\mathrm{LH}$, FSH, and GnRH-R as well as displaying the appropriate responses to GnRH with dose-dependent increase in LH secretion (9496). Furthermore, $L \beta T 2$ cells express both GPR147 and GPR74 $(59,93)$, indicating that $\mathrm{L} \beta \mathrm{T} 2$ is an appropriate cellular model system to investigate $\mathrm{GnIH}$ action occurring in gonadotropes.

In this study using L $\beta \mathrm{T} 2$ cells, GnRH treatment activates CRE activities, and GnIH effectively suppresses GnRH-induced CRE activities in a dose-dependent manner as well as cAMP production (93). GnIH also inhibits the downstream ERK phosphorylation via AC/PKA-dependent manner (Figure 1). The AC/cAMP/PKA-dependent inhibitory effect of $\mathrm{GnIH}$ are also demonstrated in GnRH-stimulated transcriptions of gonadotropin subunit genes, LH $\beta, \mathrm{FSH} \beta$, and common $\alpha$ subunit. The inhibitory effect of GnIH on GnRH-induced CRE activity, ERK phosphorylation, and gonadotropin expression leads to reduction in LH levels in L $\beta$ T2 cells. This study suggests that as in GnRH neurons (described in section Inhibitory action of GnIH on VIP/VPAC2 signaling and its physiological significance), GnIH specifically acts via cAMP pathway in its target cells (93).

\section{COMMON GNIH INHIBITORY MECHANISM IN ITS TARGET CELLS}

From the identification of GPR147 and GPR74 as GnIH-Rs (9-12), suppression of cAMP production by GnIH has been shown in several studies $(10,13,14)$. The precise mechanism of $\mathrm{GnIH}$ action in hypothalamic GnRH neurons as well as pituitary gonadotropes has been investigated in the cellular model systems through the molecular approaches on GPCR-related second messenger activity, downstream MAPK cascade, and the effect of pharmacological modulators. The results obtained by analysis of signaling pathway suggest that GnIH may play as a brake by preventing the excessive action of stimulatory inputs to maintain the balance in reproductive system. As a conserved mechanism of GnIH action, the AC/cAMP/PKA-specific inhibitory pathway has been demonstrated in hypothalamus-pituitary levels (60, 93) (Figure 1). Therefore, GnIH may govern the hypothalamic neuronal activities of GnRH by inhibiting the action of VIP and kisspeptin directly or indirectly, thus eventually reduce pituitary gonadotropin secretion. However, there are several exceptions of 
the GnIH effect on GnRH/LH release. There is a report showing that acute central injection of GnIH induces c-Fos expression in $\mathrm{GnRH}$ neurons and increases $\mathrm{LH}, \mathrm{FSH}$, and testosterone secretion in Syrian hamster (76). Similarly, GnIH has shown the dose-dependent stimulatory effect on LH secretion in adult male mice (97). In male Siberian hamsters, central administration of GnIH inhibits LH release in long day photoperiods, whereas stimulates LH release in short day, indicating that GnIH peptides finely tune LH levels in an opposite fashion across the seasons (21). Based on the complex regulation of $\mathrm{GnIH}$ action depending on the species/sexes, seasons and reproductive stages, future research is needed to determine when and how GnIH exerts its inhibitory or stimulatory effect in target cells.

\section{REGULATORY MECHANISM OF GNIH EXPRESSION BY GLUCOCORTICOID AND THYROID HORMONE}

Considering the role of $\mathrm{GnIH}$ as an upstream regulator of the hypothalamic-pituitary-gonadal (HPG) axis, abnormal GnIH expression levels may cause reproductive dysfunctions. Therefore, we discuss some endocrine regulators leading to GnIH expressional changes. See the recent review (31) for the regulatory mechanism of $\mathrm{GnIH}$ expression by melatonin and photoperiod $(19,21,98)$.

\section{Molecular Mechanism of Glucocorticoid-Mediated GnIH Activation}

Reproductive function is suppressed under stress (99-101), suggesting the interaction between hypothalamic-pituitaryadrenal (HPA) and HPG axes. From the inhibitory role of GnIH in reproduction, the GnIH system could be a good candidate mediating stress-induced reproductive dysfunction. Supporting this, there have been several studies showing that stress activates the GnIH system in birds and mammals. In adult house sparrows, capture-handling stress shows a significant increase in the number of GnIH neurons (102). In rat, immobilization stress leads to an up-regulation of GnIH expression (103) and stressful stimuli increase the expression of c-Fos protein in $\mathrm{GnIH}$ neurons of the DMH (104). These results suggest that suppressive effects of stress upon reproductive functions are mediated by the hypothalamic GnIH system. The inhibitory effect of stress on reproductive function is potentially mediated by high concentrations of circulating glucocorticoids (GC) acting via the GC receptor $(\mathrm{GR})(105,106)$. In adult rat, approximately half of hypothalamic GnIH neurons express GR (103). In quail, most GnIH-positive cells express GR mRNA and $24 \mathrm{~h}$ treatment with corticosterone (CORT) increases GnIH mRNA expression (107).

Using a GnIH-expressing neuronal cell line, rHypoE-23 derived from rat hypothalamus (108), the detailed molecular mechanism of GC-mediated GnIH transcriptional activation has been investigated (107). rHypoE-23 cells express GR mRNA and GnIH mRNA expression is activated by $24 \mathrm{~h}$ CORT treatment. There exist several glucocorticoid response elements (GREs) in the upstream of rat $\mathrm{GnIH}$ precursor coding region. Through promoter analysis, it has been identified that $-1,530$ bp GRE

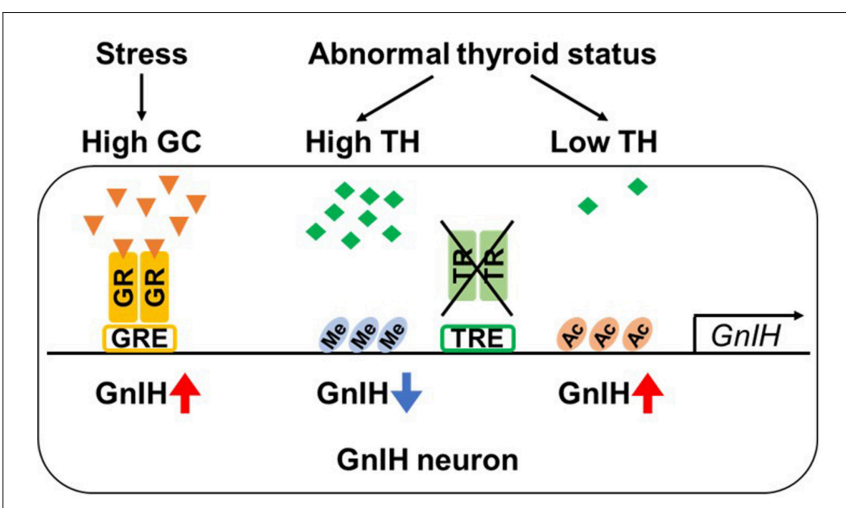

FIGURE 2 | Regulation of GnIH promoter activity by glucocorticoid and thyroid hormone. GnlH expression is regulated by glucocorticoid (GC). GnIH neurons express GC receptor (GR) and GC-response element (GRE) is present in $\mathrm{GnlH}$ promoter region. Stress increases $\mathrm{GC}$ levels, and $\mathrm{GC}$ acts by binding to $\mathrm{GR}$. When GC-bound GR is recruited to GRE, GnlH expression is up-regulated. $\mathrm{GnlH}$ expression is also actively changed by concentration of thyroid hormone (TH). Although GnlH neurons express TH receptors (TR $\alpha$ and $\beta$ ) and putative TH-response elements (TREs) exist in GnlH promoter region, TRs do not directly bind to $\mathrm{GnlH}$ promoter. However, thyroid status highly regulates the chromatin modification of $\mathrm{GnlH}$ promoter. Hypothyroidism exhibits increased $\mathrm{GnIH}$ expression with hyperacetylation of $\mathrm{H3}(\mathrm{Ac})$ in promoter region. On the other hand, hyperthyroidism decreases $\mathrm{GnIH}$ expression associated with H3K9tri-methylation (Me).

is critical for the CORT-stimulated GR recruitment and its transcriptional activity (107) (Figure 2). This study provides a putative molecular basis for transcriptional activation of GnIH under stress by demonstrating that CORT directly induces GnIH transcription by recruitment of GR to its promoter. Another study using the rHypoE-23 GnIH neuronal cells has shown that the GC agonist, dexamethasone (DEX), which directly acts on GR, increases GnIH and GPR147 mRNA levels (109). The effect of neonatal DEX exposure on reproductive maturation has been also investigated in female mice (110). DEX-treated females have exhibited delayed pubertal onset and irregular estrus cycles with decreased GnRH mRNA expression in the POA and increased $\mathrm{GnIH}$ cell numbers in the $\mathrm{DMH}$, suggesting that DEX-mediated activation of GnIH system may lead to inhibition of GnRH expression.

\section{Thyroid Hormone-Mediated GnIH Regulation by Chromatin Modification}

Recently, thyroid hormones (THs; thyroxine, $\mathrm{T}_{4}$ and triiodothyronine, $T_{3}$ ) have been suggested as a novel hormonal regulator of $\mathrm{GnIH}$ expression $(111,112)$. THs play an important role in proper development and function of the reproductive system, particularly in pubertal onset $(113,114)$, indicating interactions between the hypothalamic-pituitary-thyroid (HPT) and HPG axes. Therefore, thyroid disorders such as hypothyroidism and hyperthyroidism, cause abnormal puberty (115-117). Kiyohara et al. showed that hypothyroidism induced by long-term administration of propylthiouracil (PTU) in juvenile female mice leads to delayed pubertal onset with increased GnIH expression and reduced pituitarygonadal activity, and knockout of GnIH prevents the effect 
of hypothyroidism to delay the pubertal onset. In contrast, hyperthyroidism induced by $\mathrm{T}_{4}$ leads to a decrease in $\mathrm{GnIH}$ expression, although pubertal onset was normal. Further, $\mathrm{T}_{3}$ treatment suppresses GnIH mRNA expression in hypothalamic explants. Although GnIH neurons express TH receptors, TR $\alpha$ and TR $\beta$, and putative TH-response elements (TREs) are present in mouse GnIH promoter, TRs do not directly bind to GnIH promoter (111). As the molecular mechanism by which different $\mathrm{TH}$ concentration results in GnIH expressional changes, Kiyohara et al. have also demonstrated that the thyroid status highly regulates the chromatin modifications of $\mathrm{GnIH}$ promoter to activate and repress $\mathrm{GnIH}$ expression by H3acetylation and H3K9tri-methylation, respectively (Figure 2). Although to date limited information is available for the TH-mediated GnIH regulation, this study indicates a novel function of $\mathrm{GnIH}$ to mediate HPT-HPG interactions that contribute to proper pubertal development.

\section{CONCLUSION}

The endocrine systems, HPA, HPG and HPT axes are closely connected, thus hormonal imbalance leads to reproductive dysfunctions. As a key hypothalamic inhibitor, GnIH may act on the most upstream level of the HPG axis by regulating the hypothalamic GnRH and kisspeptin neurons as well as

\section{REFERENCES}

1. Tsutsui K, Saigoh E, Ukena K, Teranishi H, Fujisawa Y, Kikuchi M, et al. A novel avian hypothalamic peptide inhibiting gonadotropin release. Biochem Biophys Res Commun. (2000) 275:661-7. doi: 10.1006/bbrc.2000.3350

2. Tsutsui K. A new key neurohormone controlling reproduction, gonadotropin-inhibitory hormone $(\mathrm{GnIH})$ : Biosynthesis, mode of action and functional significance. Prog Neurobiol. (2009) 88:76-88. doi: 10.1016/j.pneurobio.2009.02.003

3. Tsutsui K, Bentley GE, Bedecarrats G, Osugi T, Ubuka T, Kriegsfeld LJ. Gonadotropin-inhibitory hormone $(\mathrm{GnIH})$ and its control of central and peripheral reproductive function. Front Neuroendocrinol. (2010) 31:284-95. doi: 10.1016/j.yfrne.2010.03.001

4. Tsutsui K, Ubuka T, Bentley GE, Kriegsfeld LJ. Review: regulatory mechanisms of gonadotropin-inhibitory hormone $(\mathrm{GnIH})$ synthesis and release in photoperiodic animals. Front Neurosci. (2013) 7:60. doi: $10.3389 /$ fnins. 2013.00060

5. Ukena K, Tsutsui K. Distribution of novel RFamide-related peptide-like immunoreactivity in the mouse central nervous system. Neurosci Lett. (2001) 300:153-6. doi: 10.1016/S0304-3940(01)01583-X

6. Ubuka T, Lai H, Kitani M, Suzuuchi A, Pham V, Cadigan PA, et al. Gonadotropin-inhibitory hormone identification, cDNA cloning, and distribution in rhesus macaque brain. J Comp Neurol. (2009) 517:841-55. doi: $10.1002 /$ cne. 22191

7. Ubuka T, Morgan K, Pawson AJ, Osugi T, Chowdhury VS, Minakata H, et al. Identification of human GnIH homologs, RFRP-1 and RFRP-3, and the cognate receptor, GPR147 in the human hypothalamic pituitary axis. PLoS ONE (2009) 4:e8400. doi: 10.1371/journal.pone.0008400

8. Ubuka T, Son YL, Tsutsui K. Molecular, cellular, morphological, physiological and behavioral aspects of gonadotropin-inhibitory hormone. Gen Comp Endocrinol. (2016) 227:27-50. doi: 10.1016/j.ygcen.2015.09.009

9. Bonini JA, Jones KA, Adham N, Forray C, Artymyshyn R, Durkin $\mathrm{MM}$, et al. Identification and characterization of two $\mathrm{G}$ protein-coupled receptors for neuropeptide FF. J Biol Chem. (2000) 275:39324-31. doi: 10.1074/jbc.M004385200 pituitary gonadotrope activity. The significance of GnIH system on reproduction has been emphasized by identifying the novel function of $\mathrm{GnIH}$ system and its interaction with other endocrine systems of HPA and HPT via GC and TH, respectively. Changes in $\mathrm{GnIH}$ expression levels by these endocrine modulators will alter $\mathrm{GnRH}$ neuronal activity and gonadotropin release by specifically acting on AC/cAMP/PKA pathway. Based on the complex regulatory system of endocrine interactions, it is also expected to uncover a novel involvement of $\mathrm{GnIH}$ system in reproductive regulation. The precise molecular mechanism for $\mathrm{GnIH}$ action and identification of molecular target for $\mathrm{GnIH}$ regulation may contribute to the development of new pharmaceuticals.

\section{AUTHOR CONTRIBUTIONS}

YLS wrote the manuscript. TU and KT edited the manuscript.

\section{FUNDING}

This work was supported in part by Grants-in-Aid for Scientific Research 22132004 (KT) and 22227002 (KT) and Grants-in-Aid for JSPS Fellows 2402082 (YLS) and 15F15909 (YLS) from the Ministry of Education, Science, and Culture, Japan.
10. Hinuma S, Shintani Y, Fukusumi S, Iijima N, Matsumoto Y, Hosoya $\mathrm{M}$, et al. New neuropeptides containing carboxy-terminal RFamide and their receptor in mammals. Nat Cell Biol. (2000) 2:703-8. doi: 10.1038/ 35036326

11. Ikemoto T, Park MK. Chicken RFamide-related peptide $(\mathrm{GnIH})$ and two distinct receptor subtypes: identification, molecular characterization, and evolutionary considerations. J Reprod Dev. (2005) 51:359-77. doi: $10.1262 /$ jrd. 16087

12. Yin H, Ukena K, Ubuka T, Tsutsui K. A novel G protein-coupled receptor for gonadotropin-inhibitory hormone in the Japanese quail (Coturnix japonica): identification, expression and binding activity. J Endocrinol. (2005) 184:25766. doi: 10.1677/joe.1.05926

13. Mollereau C, Mazarguil H, Marcus D, Quelven I, Kotani M, Lannoy V, et al. Pharmacological characterization of human $\operatorname{NPFF}(1)$ and $\operatorname{NPFF}(2)$ receptors expressed in CHO cells by using NPY Y(1) receptor antagonists. Eur J Pharmacol. (2002) 451:245-56. doi: 10.1016/S0014-2999(02)02224-0

14. Gouarderes C, Mazarguil H, Mollereau C, Chartrel N, Leprince J, Vaudry $\mathrm{H}$, et al. Functional differences between NPFF1 and NPFF2 receptor coupling: high intrinsic activities of RFamide-related peptides on stimulation of [35S]GTPgammaS binding. Neuropharmacology (2007) 52:376-86. doi: 10.1016/j.neuropharm.2006.07.034

15. Ubuka T, Son YL, Bentley GE, Millar RP, Tsutsui K. Gonadotropin-inhibitory hormone $(\mathrm{GnIH})$, GnIH receptor and cell signaling. Gen Comp Endocrinol. (2013) 190:10-7. doi: 10.1016/j.ygcen.2013.02.030

16. Ubuka $\mathrm{T}$, Ueno $\mathrm{M}$, Ukena $\mathrm{K}$, Tsutsui $\mathrm{K}$. Developmental changes in gonadotropin-inhibitory hormone in the Japanese quail (Coturnix japonica) hypothalamo-hypophysial system. J Endocrinol. (2003) 178:311-8. doi: $10.1677 /$ joe. 0.1780311

17. Ukena K, Ubuka T, Tsutsui K. Distribution of a novel avian gonadotropininhibitory hormone in the quail brain. Cell Tissue Res. (2003) 312:73-9. doi: 10.1007/s00441-003-0700-x

18. Kriegsfeld LJ, Mei DF, Bentley GE, Ubuka T, Mason AO, Inoue K, et al. Identification and characterization of a gonadotropin-inhibitory system in the brains of mammals. Proc Natl Acad Sci USA. (2006) 103:2410-5. doi: 10.1073/pnas.0511003103 
19. Revel FG, Saboureau M, Pevet P, Simonneaux V, Mikkelsen JD. RFamide-related peptide gene is a melatonin-driven photoperiodic gene. Endocrinology (2008) 149:902-12. doi: 10.1210/en.2007-0848

20. Legagneux K, Bernard-Franchi G, Poncet F, La Roche A, Colard C, Fellmann D, et al. Distribution and genesis of the RFRP-producing neurons in the rat brain: comparison with melanin-concentrating hormoneand hypocretin-containing neurons. Neuropeptides (2009) 43:13-9. doi: 10.1016/j.npep.2008.11.001

21. Ubuka T, Inoue K, Fukuda Y, Mizuno T, Ukena K, Kriegsfeld LJ, et al. Identification, expression, and physiological functions of Siberian hamster gonadotropin-inhibitory hormone. Endocrinology (2012) 153:37385. doi: 10.1210/en.2011-1110

22. Bentley GE, Perfito N, Ukena K, Tsutsui K, Wingfield JC. Gonadotropininhibitory peptide in song sparrows (Melospiza melodia) in different reproductive conditions, and in house sparrows (Passer domesticus) relative to chicken-gonadotropin-releasing hormone. J Neuroendocrinol. (2003) 15:794-802. doi: 10.1046/j.1365-2826.2003.01062.x

23. Smith JT, Coolen LM, Kriegsfeld LJ, Sari IP, Jaafarzadehshirazi MR, Maltby $\mathrm{M}$, et al. Variation in kisspeptin and RFamide-related peptide (RFRP) expression and terminal connections to gonadotropin-releasing hormone neurons in the brain: a novel medium for seasonal breeding in the sheep. Endocrinology (2008) 149:5770-82. doi: 10.1210/en.2008-0581

24. Kriegsfeld LJ, Gibson EM, Williams WP III, Zhao S, Mason AO, Bentley GE, et al. The roles of RFamide-related peptide- 3 in mammalian reproductive function and behaviour. J Neuroendocrinol. (2010) 22:692-700. doi: 10.1111/j.1365-2826.2010.02031.x

25. Rizwan MZ, Poling MC, Corr M, Cornes PA, Augustine RA, Quennell $\mathrm{JH}$, et al. RFamide-related peptide-3 receptor gene expression in $\mathrm{GnRH}$ and kisspeptin neurons and GnRH-dependent mechanism of action. Endocrinology (2012) 153:3770-9. doi: 10.1210/en.2012-1133

26. Clarke IJ, Sari IP, Qi Y, Smith JT, Parkington HC, Ubuka T, et al. Potent action of RFamide-related peptide-3 on pituitary gonadotropes indicative of a hypophysiotropic role in the negative regulation of gonadotropin secretion. Endocrinology (2008) 149:5811-21. doi: 10.1210/en.2008-0575

27. Maddineni S, Ocon-Grove OM, Krzysik-Walker SM, Hendricks GL III, Proudman JA, Ramachandran R. Gonadotrophin-inhibitory hormone receptor expression in the chicken pituitary gland: potential influence of sexual maturation and ovarian steroids. J Neuroendocrinol. (2008) 20:107888. doi: 10.1111/j.1365-2826.2008.01765.x

28. Ubuka T, Son YL, Tobari Y, Tsutsui K. Gonadotropin-inhibitory hormone action in the brain and pituitary. Front Endocrinol. (2012) 3:148. doi: 10.3389/fendo.2012.00148

29. Ubuka T, Son YL, Tobari Y, Narihiro M, Bentley GE, Kriegsfeld LJ, et al. Central and direct regulation of testicular activity by gonadotropininhibitory hormone and its receptor. Front Endocrinol. (2014) 5:8. doi: 10.3389/fendo.2014.00008

30. Tsutsui K, Ubuka T, Son YL, Bentley GE, Kriegsfeld LJ. Contribution of $\mathrm{GnIH}$ research to the progress of reproductive neuroendocrinology. Front Endocrinol. (2015) 6:179. doi: 10.3389/fendo.2015.00179

31. Tsutsui $\mathrm{K}$, Ubuka $\mathrm{T}$. How to contribute to the progress of neuroendocrinology: discovery of gnih and progress of $\mathrm{GnIH}$ research Front Endocrinol. (2018) 6:179. doi: 10.3389/fendo.2018.00662

32. Ducret E, Anderson GM, Herbison AE. RFamide-related peptide-3, a mammalian gonadotropin-inhibitory hormone ortholog, regulates gonadotropin-releasing hormone neuron firing in the mouse. Endocrinology (2009) 150:2799-804. doi: 10.1210/en.2008-1623

33. Wu M, Dumalska I, Morozova E, van den Pol AN, Alreja M. Gonadotropin inhibitory hormone inhibits basal forebrain vGluT2-gonadotropin-releasing hormone neurons via a direct postsynaptic mechanism. J Physiol. (2009) 587(Pt 7):1401-11. doi: 10.1113/jphysiol.2008.166447

34. Anderson GM, Relf HL, Rizwan MZ, Evans JJ. Central and peripheral effects of RFamide-related peptide-3 on luteinizing hormone and prolactin secretion in rats. Endocrinology (2009) 150:1834-40. doi: 10.1210/en.2008-1359

35. Lee JH, Miele ME, Hicks DJ, Phillips KK, Trent JM, Weissman BE, et al. KiSS1, a novel human malignant melanoma metastasis-suppressor gene. J Natl Cancer Inst. (1996) 88:1731-7. doi: 10.1093/jnci/88.23.1731
36. de Roux N, Genin E, Carel JC, Matsuda F, Chaussain JL, Milgrom E. Hypogonadotropic hypogonadism due to loss of function of the KiSS1derived peptide receptor GPR54. Proc Natl Acad Sci USA. (2003) 100:109726. doi: 10.1073/pnas.1834399100

37. Funes S, Hedrick JA, Vassileva G, Markowitz L, Abbondanzo S, Golovko A, et al. The KiSS-1 receptor GPR54 is essential for the development of the murine reproductive system. Biochem Biophys Res Commun. (2003) 312:1357-63. doi: 10.1016/j.bbrc.2003.11.066

38. Seminara SB, Messager S, Chatzidaki EE, Thresher RR, Acierno JS Jr, Shagoury, J.K, et al. The GPR54 gene as a regulator of puberty. N Engl J Med. (2003) 349:1614-27. doi: 10.1056/NEJMoa035322

39. Han SK, Gottsch ML, Lee KJ, Popa SM, Smith JT, Jakawich SK, et al. Activation of gonadotropin-releasing hormone neurons by kisspeptin as a neuroendocrine switch for the onset of puberty. J Neurosci. (2005) 25:1134956. doi: 10.1523/JNEUROSCI.3328-05.2005

40. Dumalska I, Wu M, Morozova E, Liu R, van den Pol A, Alreja M. Excitatory effects of the puberty-initiating peptide kisspeptin and group I metabotropic glutamate receptor agonists differentiate two distinct subpopulations of gonadotropin-releasing hormone neurons. J Neurosci. (2008) 28:8003-13. doi: 10.1523/JNEUROSCI.1225-08.2008

41. Kinoshita M, Tsukamura H, Adachi S, Matsui H, Uenoyama Y, Iwata K, et al. Involvement of central metastin in the regulation of preovulatory luteinizing hormone surge and estrous cyclicity in female rats. Endocrinology (2005) 146:4431-6. doi: 10.1210/en.2005-0195

42. Clarkson J, Herbison AE. Postnatal development of kisspeptin neurons in mouse hypothalamus; sexual dimorphism and projections to gonadotropinreleasing hormone neurons. Endocrinology (2006) 147:5817-25. doi: 10.1210/en.2006-0787

43. Messager S, Chatzidaki EE, Ma D, Hendrick AG, Zahn D, Dixon J, et al. Kisspeptin directly stimulates gonadotropin-releasing hormone release via G protein-coupled receptor 54. Proc Natl Acad Sci USA. (2005) 102:1761-6. doi: 10.1073/pnas.0409330102

44. Kotani M, Detheux M, Vandenbogaerde A, Communi D, Vanderwinden JM, Le Poul E, et al. The metastasis suppressor gene KiSS-1 encodes kisspeptins, the natural ligands of the orphan $\mathrm{G}$ protein-coupled receptor GPR54. J Biol Chem. (2001) 276:34631-6. doi: 10.1074/jbc.M104847200

45. Colledge WH. Kisspeptins and GnRH neuronal signalling. Trends Endocrinol Metab. (2009) 20:115-21. doi: 10.1016/j.tem.2008.10.005

46. van der Beek EM, Horvath TL, Wiegant VM, Van den Hurk R, Buijs RM. Evidence for a direct neuronal pathway from the suprachiasmatic nucleus to the gonadotropin-releasing hormone system: combined tracing and light and electron microscopic immunocytochemical studies. J Comp Neurol. (1997) 384:569-79. doi: 10.1002/(SICI)1096-9861(19970811)384:4<569::AID-CNE6>3.0.CO;2-0

47. Horvath TL, Cela V, van der Beek EM. Gender-specific apposition between vasoactive intestinal peptide-containing axons and gonadotrophin-releasing hormone-producing neurons in the rat. Brain Res. (1998) 795:277-81. doi: 10.1016/S0006-8993(98)00208-X

48. Smith MJ, Jiennes L, Wise PM. Localization of the VIP2 receptor protein on GnRH neurons in the female rat. Endocrinology (2000) 141:4317-20. doi: 10.1210 /endo.141.11.7876

49. McCulloch DA, MacKenzie CJ, Johnson MS, Robertson DN, Holland PJ, Ronaldson E, et al. Additional signals from VPAC/PAC family receptors. Biochem Soc Trans. (2002) 30:441-6. doi: 10.1042/bst0300441

50. Lee WS, Smith MS, Hoffman GE. Luteinizing hormone-releasing hormone neurons express Fos protein during the proestrous surge of luteinizing hormone. Proc Natl Acad Sci USA. (1990) 87:5163-7. doi: $10.1073 /$ pnas.87.13.5163

51. van der Beek EM, van Oudheusden HJ, Buijs RM, van der Donk HA, van den Hurk R, Wiegant VM. Preferential induction of cfos immunoreactivity in vasoactive intestinal polypeptide-innervated gonadotropin-releasing hormone neurons during a steroid-induced luteinizing hormone surge in the female rat. Endocrinology (1994) 134:2636-44. doi: 10.1210/endo.134.6.8194489

52. Harney JP, Scarbrough $\mathrm{K}$, Rosewell $\mathrm{KL}$, Wise $\mathrm{PM}$. In vivo antisense antagonism of vasoactive intestinal peptide in the suprachiasmatic nuclei causes aging-like changes in the estradiol-induced luteinizing 
hormone and prolactin surges. Endocrinology (1996) 137:3696-701. doi: 10.1210/endo.137.9.8756535

53. Gerhold LM, Rosewell KL, Wise PM. Suppression of vasoactive intestinal polypeptide in the suprachiasmatic nucleus leads to aging-like alterations in cAMP rhythms and activation of gonadotropin-releasing hormone neurons. J Neurosci. (2005) 25:62-7. doi: 10.1523/JNEUROSCI.3598-04.2005

54. Christian CA, Moenter SM. Vasoactive intestinal polypeptide can excite gonadotropin-releasing hormone neurons in a manner dependent on estradiol and gated by time of day. Endocrinology (2008) 149:3130-6. doi: 10.1210/en.2007-1098

55. Mellon PL, Windle JJ, Goldsmith PC, Padula CA, Roberts JL, Weiner RI. Immortalization of hypothalamic GnRH neurons by genetically targeted tumorigenesis. Neuron (1990) 5:1-10. doi: 10.1016/0896-6273(90)90028-E

56. Mellon PL, Wetsel WC, Windle JJ, Valenca MM, Goldsmith PC, Whyte DB, et al. Immortalized hypothalamic gonadotropin-releasing hormone neurons. Ciba Found Symp. (1992) 168:104-17. Discussion 117-26.

57. Novaira HJ, Ng Y, Wolfe A, Radovick S. Kisspeptin increases GnRH mRNA expression and secretion in GnRH secreting neuronal cell lines. Mol Cell Endocrinol. (2009) 311:126-34. doi: 10.1016/j.mce.2009.06.011

58. Tonsfeldt KJ, Goodall CP, Latham KL, Chappell PE. Oestrogen induces rhythmic expression of the Kisspeptin-1 receptor GPR54 in hypothalamic gonadotrophin-releasing hormone-secreting GT1-7 cells. J Neuroendocrinol. (2011) 23:823-30. doi: 10.1111/j.1365-2826.2011.02188.x

59. Sukhbaatar U, Kanasaki H, Mijiddorj T, Oride A, Miyazaki K. Expression of gonadotropin-inhibitory hormone receptors in mouse pituitary gonadotroph LbetaT2 cells and hypothalamic gonadotropinreleasing hormone-producing GT1-7 cells. Endocr J. (2014) 61:25-34. doi: 10.1507/endocri.EJ13-0238

60. Son YL, Ubuka T, Soga T, Yamamoto K, Bentley GE, Tsutsui K. Inhibitory action of gonadotropin-inhibitory hormone on the signaling pathways induced by kisspeptin and vasoactive intestinal polypeptide in GnRH neuronal cell line, GT1-7. Faseb J. (2016) 30:2198-210. doi: $10.1096 /$ fj.201500055

61. Zhao S, Kriegsfeld LJ. Daily changes in GT1-7 cell sensitivity to GnRH secretagogues that trigger ovulation. Neuroendocrinology (2009) 89:448-57. doi: $10.1159 / 000192370$

62. Novaira HJ, Fadoju D, Diaczok D, Radovick S. Genetic mechanisms mediating kisspeptin regulation of GnRH gene expression. J Neurosci. (2012) 32:17391-400. doi: 10.1523/JNEUROSCI.2438-12.2012

63. Sukhbaatar U, Kanasaki H, Mijiddorj T, Oride A, Miyazaki K. Kisspeptin induces expression of gonadotropin-releasing hormone receptor in $\mathrm{GnRH}$ producing GT1-7 cells overexpressing G protein-coupled receptor 54. Gen Comp Endocrinol. (2013) 194:94-101. doi: 10.1016/j.ygcen.2013.09.002

64. Nichols R, Demers LA, Larsen BM, Robinson D, Converso K, Russell MW, et al. Human RFamide-related peptide-1 diminishes cellular and integrated cardiac contractile performance. Peptides (2013) 31:2067-74. doi: 10.1016/j.peptides.2010.07.012

65. Gojska NM, Friedman Z, Belsham DD. Direct regulation of gonadotrophinreleasing hormone $(\mathrm{GnRH})$ transcription by RF-amide-related peptide-3 and kisspeptin in a novel GnRH-secreting cell line, mHypoA-GnRH/GFP. J Neuroendocrinol. (2014) 26:888-97. doi: 10.1111/jne.12225

66. Poling MC, Quennell JH, Anderson GM, Kauffman AS. Kisspeptin neurones do not directly signal to RFRP-3 neurones but RFRP-3 may directly modulate a subset of hypothalamic kisspeptin cells in mice. J Neuroendocrinol. (2013) 25:876-86. doi: 10.1111/jne.12084

67. Olcese J, McArdle CA, Middendorff R, Greenland K. Pituitary adenylate cyclase-activating peptide and vasoactive intestinal peptide receptor expression in immortalized LHRH neurons. J Neuroendocrinol. (1997) 9:937-43. doi: 10.1046/j.1365-2826.1997.00663.x

68. Mahata SK, Mahata M, Livsey CV, Gerdes HH, Huttner WB, O'Connor DT. Neuroendocrine cell type-specific and inducible expression of the secretogranin II gene: crucial role of cyclic adenosine monophosphate and serum response elements. Endocrinology (1999) 140:739-49. doi: 10.1210/endo.140.2.6476

69. Krajnak K, Kashon ML, Rosewell KL, Wise PM. Aging alters the rhythmic expression of vasoactive intestinal polypeptide mRNA but not arginine vasopressin mRNA in the suprachiasmatic nuclei of female rats. J Neurosci. (1998) 18:4767-74. doi: 10.1523/JNEUROSCI.18-12-04767.1998
70. Colwell CS, Michel S, Itri J, Rodriguez W, Tam J, Lelievre V, et al. Disrupted circadian rhythms in VIP- and PHI-deficient mice. Am J Physiol Regul Integr Comp Physiol. (2003) 285:R939-949. doi: 10.1152/ajpregu.00200.2003

71. Clarke IJ, Smith JT, Henry BA, Oldfield BJ, Stefanidis A, Millar RP, et al. Gonadotropin-inhibitory hormone is a hypothalamic peptide that provides a molecular switch between reproduction and feeding. Neuroendocrinology (2012) 95:305-16. doi: 10.1159/000332822

72. Henningsen JB, Ancel C, Mikkelsen JD, Gauer F, Simonneaux V. Roles of RFRP-3 in the daily and seasonal regulation of reproductive activity in female syrian hamsters. Endocrinology (2017) 158:652-63. doi: 10.1210/en.2016-1689

73. Russo KA, La JL, Stephens SB, Poling MC, Padgaonkar NA, Jennings KJ, et al. Circadian control of the female reproductive axis through gated responsiveness of the RFRP-3 system to VIP signaling. Endocrinology (2015) 156:2608-18. doi: 10.1210/en.2014-1762

74. Small TW, Sharp PJ, Bentley GE, Deviche P. Relative photorefractoriness, prolactin, and reproductive regression in a flexibly breeding sonoran desert passerine, the rufous-winged sparrow, Aimophila carpalis. J Biol Rhythms (2008) 23:69-80. doi: 10.1177/0748730407310790

75. Rizwan MZ, Porteous R, Herbison AE, Anderson GM. Cells expressing RFamide-related peptide-1/3, the mammalian gonadotropin-inhibitory hormone orthologs, are not hypophysiotropic neuroendocrine neurons in the rat. Endocrinology (2009) 150:1413-20. doi: 10.1210/en.2008-1287

76. Ancel C, Bentsen AH, Sebert ME, Tena-Sempere M, Mikkelsen JD, Simonneaux V. Stimulatory effect of RFRP-3 on the gonadotrophic axis in the male Syrian hamster: the exception proves the rule. Endocrinology (2012) 153:1352-63. doi: 10.1210/en.2011-1622

77. Johnson MA, Tsutsui K, Fraley GS. Rat RFamide-related peptide-3 stimulates GH secretion, inhibits LH secretion, and has variable effects on sex behavior in the adult male rat. Horm Behav. (2007) 51:171-80. doi: 10.1016/j.yhbeh.2006.09.009

78. Murakami $M$, Matsuzaki $T$, Iwasa $T$, Yasui $T$, Irahara $M$, Osugi $\mathrm{T}$, et al. Hypophysiotropic role of RFamide-related peptide-3 in the inhibition of LH secretion in female rats. J Endocrinol. (2008) 199:105-12. doi: 10.1677/JOE-08-0197

79. Kadokawa H, Shibata M, Tanaka Y, Kojima T, Matsumoto K, Oshima K, et al. Bovine C-terminal octapeptide of RFamide-related peptide-3 suppresses luteinizing hormone $(\mathrm{LH})$ secretion from the pituitary as well as pulsatile LH secretion in bovines. Domest Anim Endocrinol. (2009) 36:219-24. doi: 10.1016/j.domaniend.2009.02.001

80. Smith JT, Young IR, Veldhuis JD, Clarke IJ. Gonadotropin-inhibitory hormone $(\mathrm{GnIH})$ secretion into the ovine hypophyseal portal system. Endocrinology (2012) 153:3368-75. doi: 10.1210/en.2012-1088

81. Seeburg PH, Mason AJ, Stewart TA, Nikolics K. The mammalian GnRH gene and its pivotal role in reproduction. Recent Prog Horm Res. (1987) 43:69-98. doi: 10.1016/B978-0-12-571143-2.50008-3

82. Millar RP, Lu ZL, Pawson AJ, Flanagan CA, Morgan K, Maudsley SR. Gonadotropin-releasing hormone receptors. Endocr Rev. (2004) 25:235-75. doi: 10.1210/er.2003-0002

83. Naor Z. Signaling by G-protein-coupled receptor (GPCR): studies on the GnRH receptor. Front Neuroendocrinol. (2009) 30:10-29. doi: 10.1016/j.yfrne.2008.07.001

84. Dobkin-Bekman M, Naidich M, Pawson AJ, Millar RP, Seger R, Naor Z. Activation of mitogen-activated protein kinase (MAPK) by GnRH is cell-context dependent. Mol Cell Endocrinol. (2006) 252:184-90. doi: 10.1016/j.mce.2006.03.035

85. Stanislaus D, Ponder S, Ji TH, Conn PM. Gonadotropin-releasing hormone receptor couples to multiple $\mathrm{G}$ proteins in rat gonadotrophs and in GGH3 cells: evidence from palmitoylation and overexpression of $\mathrm{G}$ proteins. Biol Reprod. (1998) 59:579-86. doi: 10.1095/biolreprod59.3.579

86. Liu F, Usui I, Evans LG, Austin DA, Mellon PL, Olefsky JM, et al. Involvement of both $\mathrm{G}(\mathrm{q} / 11)$ and $\mathrm{G}(\mathrm{s})$ proteins in gonadotropin-releasing hormone receptor-mediated signaling in L beta T2 cells. J Biol Chem. (2002) 277:32099-108. doi: 10.1074/jbc.M203639200

87. Han XB, Conn PM. The role of protein kinases A and C pathways in the regulation of mitogen-activated protein kinase activation in response to gonadotropin-releasing hormone receptor activation. Endocrinology (1999) 140:2241-51. doi: 10.1210/endo.140.5.6707 
88. Grosse R, Schmid A, Schoneberg T, Herrlich A, Muhn P, Schultz G, et al. Gonadotropin-releasing hormone receptor initiates multiple signaling pathways by exclusively coupling to $\mathrm{G}(\mathrm{q} / 11)$ proteins. J Biol Chem. (2000) 275:9193-200. doi: 10.1074/jbc.275.13.9193

89. Tsutsumi R, Mistry D, Webster NJ. Signaling responses to pulsatile gonadotropin-releasing hormone in LbetaT2 gonadotrope cells. J Biol Chem. (2010) 285:20262-72. doi: 10.1074/jbc.M110.132662

90. Ciccone NA, Dunn IC, Boswell T, Tsutsui K, Ubuka T, Ukena K, et al. Gonadotrophin inhibitory hormone depresses gonadotrophin alpha and follicle-stimulating hormone beta subunit expression in the pituitary of the domestic chicken. J Neuroendocrinol. (2004) 16:999-1006. doi: 10.1111/j.1365-2826.2005.01260.x

91. Sari IP, Rao A, Smith JT, Tilbrook AJ, Clarke IJ. Effect of RF-amiderelated peptide- 3 on luteinizing hormone and follicle-stimulating hormone synthesis and secretion in ovine pituitary gonadotropes. Endocrinology (2009) 150:5549-56. doi: 10.1210/en.2009-0775

92. Pineda R, Garcia-Galiano D, Sanchez-Garrido MA, Romero M, Ruiz-Pino F, Aguilar E, et al. Characterization of the inhibitory roles of RFRP3, the mammalian ortholog of $\mathrm{GnIH}$, in the control of gonadotropin secretion in the rat: in vivo and in vitro studies. Am J Physiol Endocrinol Metab. (2010) 299:E39-46. doi: 10.1152/ajpendo.00108.2010

93. Son YL, Ubuka T, Millar RP, Kanasaki H, Tsutsui K. Gonadotropin-inhibitory hormone inhibits GnRH-induced gonadotropin subunit gene transcriptions by inhibiting AC/cAMP/PKA-dependent ERK pathway in LbetaT2 cells. Endocrinology (2012) 153:2332-43. doi: 10.1210/en.2011-1904

94. Alarid ET, Windle JJ, Whyte DB, Mellon PL. Immortalization of pituitary cells at discrete stages of development by directed oncogenesis in transgenic mice. Development (1996) 122:3319-29.

95. Turgeon JL, Kimura Y, Waring DW, Mellon PL. Steroid and pulsatile gonadotropin-releasing hormone $(\mathrm{GnRH})$ regulation of luteinizing hormone and GnRH receptor in a novel gonadotrope cell line. Mol Endocrinol. (1996) 10:439-50.

96. Liu F, Austin DA, Mellon PL, Olefsky JM, Webster NJ. GnRH activates ERK1/2 leading to the induction of c-fos and LHbeta protein expression in LbetaT2 cells. Mol Endocrinol. (2002) 16:419-34. doi: 10.1210/mend.16.3.0791

97. Ancel C, Inglis MA, Anderson GM. Central RFRP-3 Stimulates LH Secretion in Male Mice and Has Cycle Stage-Dependent Inhibitory Effects in Females. Endocrinology (2017) 158:2873-83. doi: 10.1210/en.2016-1902

98. Ubuka T, Bentley GE, Ukena K, Wingfield JC, Tsutsui K. Melatonin induces the expression of gonadotropin-inhibitory hormone in the avian brain. Proc Natl Acad Sci USA. (2005) 102:3052-7. doi: 10.1073/pnas.0403840102

99. Collu R, Gibb W, Ducharme JR. Effects of stress on the gonadal function. J Endocrinol Invest. (1984) 7:529-37. doi: 10.1007/BF03348463

100. Rabin D, Gold PW, Margioris AN, Chrousos GP. Stress and reproduction: physiologic and pathophysiologic interactions between the stress and reproductive axes. Adv Exp Med Biol. (1988) 245:377-87. doi: 10.1007/978-1-4899-2064-5_29

101. Rivest S, Rivier C. The role of corticotropin-releasing factor and interleukin1 in the regulation of neurons controlling reproductive functions. Endocr Rev. (1995) 16:177-99.

102. Calisi RM, Rizzo NO, Bentley GE. Seasonal differences in hypothalamic EGR-1 and GnIH expression following capture-handling stress in house sparrows (Passer domesticus). Gen Comp Endocrinol. (2008) 157:283-7. doi: 10.1016/j.ygcen.2008.05.010

103. Kirby ED, Geraghty AC, Ubuka T, Bentley GE, Kaufer D. Stress increases putative gonadotropin inhibitory hormone and decreases luteinizing hormone in male rats. Proc Natl Acad Sci USA. (2009) 106:11324-9. doi: 10.1073/pnas.0901176106
104. Kaewwongse M, Takayanagi Y, Onaka T. Effects of RFamiderelated peptide (RFRP)-1 and RFRP-3 on oxytocin release and anxiety-related behaviour in rats. J Neuroendocrinol. (2010) 23:20-7. doi: 10.1111/j.1365-2826.2010.02077.x

105. Evans RM. The steroid and thyroid hormone receptor superfamily. Science (1988) 240:889-95. doi: 10.1126/science. 3283939

106. Ramamoorthy S, Cidlowski JA. Exploring the molecular mechanisms of glucocorticoid receptor action from sensitivity to resistance. Endocr Dev. (2013) 24:41-56. doi: 10.1159/000342502

107. Son YL, Ubuka T, Narihiro M, Fukuda Y, Hasunuma I, Yamamoto K, et al. Molecular basis for the activation of gonadotropin-inhibitory hormone gene transcription by corticosterone. Endocrinology (2014) 155:1817-26. doi: 10.1210/en.2013-2076

108. Gingerich S, Wang X, Lee PK, Dhillon SS, Chalmers JA, Koletar MM, et al. The generation of an array of clonal, immortalized cell models from the rat hypothalamus: analysis of melatonin effects on kisspeptin and gonadotropin-inhibitory hormone neurons. Neuroscience (2009) 162:113440. doi: 10.1016/j.neuroscience.2009.05.026

109. Gojska NM, Belsham DD. Glucocorticoid receptor-mediated regulation of Rfrp (GnIH) and Gpr147 (GnIH-R) synthesis in immortalized hypothalamic neurons. Mol Cell Endocrinol. (2014) 384:23-31. doi: 10.1016/j.mce.2013.12.015

110. Soga T, Dalpatadu SL, Wong DW, Parhar IS. Neonatal dexamethasone exposure down-regulates $\mathrm{GnRH}$ expression through the GnIH pathway in female mice. Neuroscience (2012) 218:56-64. doi: 10.1016/j.neuroscience.2012.05.023

111. Kiyohara M, Son YL, Tsutsui K. Involvement of gonadotropin-inhibitory hormone in pubertal disorders induced by thyroid status. Sci Rep. (2017) 7:1042. doi: 10.1038/s41598-017-01183-8

112. Tsutsui K, Son YL, Kiyohara M, Miyata I. Discovery of GnIH and Its Role in Hypothyroidism-Induced Delayed Puberty. Endocrinology (2018) 159:62-8. doi: 10.1210/en.2017-00300

113. Rivkees SA, Bode HH, Crawford JD. Long-term growth in juvenile acquired hypothyroidism: the failure to achieve normal adult stature. $N$ Engl J Med. (1988) 318:599-602. doi: 10.1056/NEJM1988031031 81003

114. Doufas AG, Mastorakos G. The hypothalamic-pituitary-thyroid axis and the female reproductive system. Ann N Y Acad Sci. (2000) 900:65-76. doi: 10.1111/j.1749-6632.2000.tb06217.x

115. Hanna CE, LaFranchi SH. Adolescent thyroid disorders. Adolesc Med. (2002) 13:13-35.

116. Weber G, Vigone MC, Stroppa L, Chiumello G. Thyroid function and puberty. J Pediatr Endocrinol Metab. (2003) 16(Suppl. 2):253-7.

117. Cabrera SM, DiMeglio LA, Eugster EA. Incidence and characteristics of pseudoprecocious puberty because of severe primary hypothyroidism. J Pediatr. (2013) 162:637-9. doi: 10.1016/j.jpeds. 2012.10.043

Conflict of Interest Statement: The authors declare that the research was conducted in the absence of any commercial or financial relationships that could be construed as a potential conflict of interest.

Copyright (C) 2019 Son, Ubuka and Tsutsui. This is an open-access article distributed under the terms of the Creative Commons Attribution License (CC BY). The use, distribution or reproduction in other forums is permitted, provided the original author(s) and the copyright owner(s) are credited and that the original publication in this journal is cited, in accordance with accepted academic practice. No use, distribution or reproduction is permitted which does not comply with these terms. 